Cortegnondente.

"Audi alteram partem."

\section{THE MICTURITION CENTRE.}

To the Editor of THE LANCET.

SiR,-In your issue of Feb. 3rd Mr. J. W. Thomson Walker, in an interesting account of the state of the bladder in man after injury to the spinal cord, makes some historical remarks on the micturition centre, which, I think, call for comment. He says-

The work of Gaskell shows that the centre for micturition lies outside the spinal cord, in the hypogastric and mesenteric plexuses of the sympathetic. Müller, applying Gaskell's view, states that after complete separation of the bladder from the cord reflex micturition still takes place.

Gaskell, I am sure, would have energetically rejected the statement that there was no micturition centre in the spinal cord. So far as I know no one who has experimented on the matter in the last 30 years has questioned its existence, although different values have been attributed to it. The existence of an additional centre outside the spinal cord has long been the subject of controversy. Sokownin ${ }^{1}$ in 1874 found that stimulation of the central end of one hypogastric nerve, after severance of all connexion with the spinal cord, caused reflex contraction of the bladder, and considered it to be a reflex like that from the spinal cord involving afferent nerve cells. The experiment was taken as supporting the current theory that peripheral ganglia connected with organs acted as reflex centres for them. It was shown by Anderson and myself ${ }^{2}$ in 1894, and by myself ${ }^{3}$ in 1900 , that the reflex did not involve afferent nerve fibres or cells, but was due to the branching of efferent fibres, one branch running to a nerve cell supplying one side of the bladder and the other to a nerve cell supplying the other side. This 1 spoke of as an axon-reflex. Goltz and Ewald ${ }^{4}$ in 1896 found that micturition returned in dogs after removal of the whole spinal cord below the upper thoracic region. Mïller ${ }^{5}$ in 1901 made experiments similar to those of Goltz and Ewald, but with less extensive removal of the spinal cord, and confirmed their results. Gaskell, ${ }^{6}$ in his book posthumously published in 1916, does not (so far as I have seen) make any mention of a micturition centre; he had not at any time made experiments with regard to it. He discusses the origin of peripheral reflexes in the bladder and elsewhere, and adopts the theory that, so far as they occur, they are due to axon-reflexes.

Cambridge, Feb. 21st, 1917

I am, Sir, yours faithfully, J. N. LANGLEY.

\section{ACUTE GASTRIC ULCER.}

To the Editor of THE LANCET.

SrR,-Between Jan. 5th and Feb. 3rd of this year six cases of acute gastric ulcer (with pronounced hæmatemesis or melæna, or both hæmatemesis and melæna) were admitted to the Connaught Hospital, Aldershot. Only two cases of a similar nature have been admitted during the previous 22 months. Six cases will, of course, prove nothing, and their occurrence at short intervals may well be within the limits of ordinary coincidence ; but the contrast between this comparatively large number and previous admissions of the same disease encourages me to speculate whether something more than coincidence might be invoked and to mention publicly the series for what it is worth as an isolated observation, in the hope that others may have noted the same "coincidence" at this or any other time. As a determining factor, mentioned merely on account of its obviousness, I suggest the protracted low temperature experienced over the whole of this period. I need not waste your valuable space with clinical details except to mention that the ages of the men were $29,32,34,37,38$, and 40 respectively; their

1 Fourth Vers. russischer Naturforscher in Kasan (Summary in Arch. f. d. ges. Physiol., x., 374).

$$
2 \text { Journ. of Physiol., xvi., } 410 .
$$$$
3 \text { Ibid., Xxv., } 364 .
$$

4 Arch. f. d. ges. Physiol., ixili., 362

5 Deutsch. Zeitschr. f. Nervenheillk, xxi., 86

6 The Involuntary Nervous System (Longmans, Green, and Co.). length of service varied from 10 days to 20 months; one case may have been of traumatic origin, none of the cases gave a history of previous hæmatemesis.

Finally, of the two previous cases referred to above, one was aged 35 , the other 51 . The elder, after repeated hæmatemesis, died, having existed upon salines for five weeks, during which time operation, which was urgently advised, was persistently refused.

I am, Sir, yours faithfully,

ADOLPHE ABRAHAMS, Temporary Captain, R.A.M.C.; Officer in Charge Medical
Feb. 6th, 1917. Division, Connaught Hospital, Aldershot.

\section{THE REPORT ON CEREBRO-SPINAL FEVER.}

To the Editor of THE LANCET.

SrR,-New results of value to bacteriology, gleaned from recent research on identification of meningococci, are recorded in the Third Special Report ${ }^{1}$ of the Medical Research Committee, and the general value of this document is enhanced by inclusion of other matters both of clinical and controversial interest. That at the onset of cerebrospinal fever the same type of organism is always present in the naso-pharynx as is to be found in the spinal fluid is a fact of great value in early diagnosis, and Captain Flack ${ }^{2}$ has shown that by plating a naso-pharyngeal swab on the spot it is possible to diagnose atypical cases within 48 hours.

Of less value seems the pronouncement ${ }^{3}$ that nasopharyngeal organisms, giving cultural and fermentative signs of meningococci, are to be rejected as pseudomeningococci unless they conform to the serological reactions of one or other of four types of meningococci, isolated from 32 cases in 1915. Admitted that these types have predominated in epidemics during 1915-16, they do not exhaust the possible number of pathogenio strains. Flexner has isolated at least 32 strains. Two strains isolated by $\mathrm{me}^{4}$ from spinal fluid were not agglutinated by antiserums from Gordon's Types 1,2, or 3, but were agglutinated by Flexner in high dilutions, and it is surely an accepted principle of medicine that any germ may become pathogenic if tissue resistance be sufficiently lowered. If so, in*gglutinable strains should be regarded as potentially pathogenic. My objection to this limitation is its possible influence on treatment. Without access to a laboratory, where the organism might be differentiated into its serological type and if atypical a serum prepared-a matter of time and distance to country practitioners-it is certainly prejudicial to the patient to surmise that the organism must conform to one of four types, or to employ a serum evolved from one of them. The indication is rather to use a multivalent serum, such as Flexner's. Fleet-Surgeon Bassett-Smith ${ }^{5}$ found that of 28 naso-pharyngeal strains 27 were agglutinated by Flexner. Of these, 21 were also tested with Gordon's serums 1 and 2 . Seven agglutinated to 1 and 13 to 2 .

Lastly, this report contains such authoritative confirmation of the theory of cerebro-spinal fever ${ }^{\circ}$ advanced by me in 1915, that I cannot but regret an absence of any endorsement of those preventive measures which should follow the correct etiology, Lieutenant-Colonel M. H. Gordon and Captain Flack ${ }^{7}$ accept spread of infection as due to floating droplets of infected naso-pharyngeal secretion from the "carrier," and as influenced by "the degree of bad ventilation or overcrowding obtaining in his immediate environment." Again, Captain Flack ${ }^{\not}$ confirms my earlier observation, embodied in a report to the War Office on Sept. 27th, 1915, that swabs and plates conveyed some distance on a cold day to a laboratory are liable to be negative. The point is that meningococci die in 30 minutes at a temperature of $62^{\circ} \mathrm{F}$.

I have contended that under conditions of fresh air it is impossible for meningococci to pass from throat to throat, and Captain Flack records a new observation on this point-" whatever the form of treatment, a spell of sunshine and dry weather markedly influenced the rate of discharge of carriers." 9 This suggests that fresh air not only prevents

1 National Health Insurance. Special Report Series. No. 3. Bacteriological Studies in the Pathology and Preventive Control of Cerebrespinal Fever among the Forces during 1915 and 1916.

$$
\begin{array}{ll}
2 \text { Loc. cit., p. } 19 & 3 \text { Ibid., p. } 14 . \\
4 \text { The LaNCET, 1915, ii., 862. } & 5 \text { Loc. cit., p. } 68 .
\end{array}
$$

6 THE LANCET, 1916, ii., 828 